\title{
STRATEGI HUBUNGAN MASYARAKAT \\ DALAM MENSOSIALISASIKAN PROGRAM "ENJOY JAKARTA" OLEH DINAS PARIWISATA DAN KEBUDAYAAN DKI JAKARTA
}

\author{
Raden Roro Astira Intan Vernadeina ${ }^{1)}$ dan Raden Roro Astari Indah Vernideani' ${ }^{2)}$ \\ ${ }^{1,2}$ Corporate Communication, Magister Ilmu Komunikasi, London School of Public Relations Jakarta \\ ${ }^{1,2}$ Sudirman Park Campus B Post Graduate LSPR, Karet, DKI Jakarta, 10220 \\ E-mail: astira.intan@gmail.com ${ }^{1)}$, astari.vernideani@gmail.com ${ }^{2)}$
}

\begin{abstract}
ABSTRAK
Pariwisata di Indonesia saat ini sedang berlari cepat untuk meningkatkan wisatawan karena Kementerian Pariwisata Indonesia tahun 2019-2020 targetnya adalah 20 juta wisatawan yang datang ke Indonesia. Jakarta merupakan Ibukota Indonesia dimana semua aktivitas berpusat di Jakarta. Suatu kota pasti mempunyai strategi pemasaran pariwisata yang dilakukan oleh Dinas Pariwisata dan Kebudayaan di kota nya. Dinas Pariwisata dan Kebudayaan DKI Jakarta sudah melakukan sosialisasi sadar wisata ke masyarakat Jakarta untuk lebih mencintai dan peduli terhadap kotanya. Teori PR Excellent menyampaikan suatu komunikasi dua arah antara organisasi kepada publiknya - publik kepada organisasi dan simetris, hal ini sudah cukup dilakukan oleh Dinas Pariwisata dan Kebudayaan DKI Jakarta, akan tetapi jika city branding Jakarta yaitu Enjoy Jakarta ingin lebih terkenal maka banyak hal lainnya yang dapat dilakukan sehingga citra Jakarta bisa dikenal lebih baik lagi.
\end{abstract}

Kata kunci: Enjoy Jakarta, PR Excellent, City Branding

\section{PENDAHULUAN}

Ketika kita berbicara tentang slogan Enjoy Jakarta, pengertian apakah yang bisa kita tawarkan sebagai masyarakat Jakarta sehingga wisatawan harus merasa Enjoy? Apakah kenyamanan Kota Jakarta? Atau justru kemacetan parah, banjir di mana-mana atau sampah berserakan? Gubernur Basuki Tjahaja Purnama memang sedang berfokus kepada infastruktur di Jakarta. Akan tetapi, hal ini bukan masalah kita sebagai masyarakat Jakarta untuk ikut menunda wisata di Jakarta.

Citra utama yang ingin Jakarta tunjukan adalah kota yang sangat unik, nyaman, menarik dan berbudaya. Sebagai pusatnya Indonesia Jakarta siap melayani setiap destinasi wisata dengan keindahan dan kenyamanan dari objek - objek wisata.

Kompetitor dari kota Jakarta adalah kota Singapore, Kuala Lumpur dan Bangkok. Karena ketiga kota tersebut mempunyai karakteristik tujuan wisata yang sama yaitu destinasi Bleisure Tourism (Business dan Leisure), yang mana di dalamnya termasuk MICE (Meeting, Incentice, Conference dan Exhibition). Sehingga Jakarta harus dapat bersaing dan melakukan inovasi agar Jakarta tetap bisa bersaing dengan ketiga kota tersebut. Generasi muda dan masyarakat sudah seharusnya mendukung pemerintah dalam memajukan pariwisata kota Jakarta (Kartajaya H, dalam pembekalan "Marketing Jakarta" Abang None DKI Jakarta 2016).

Peneliti berfikir bahwa ada yang mengganjal pada tagline Enjoy Jakarta saat ini, kenapa harus diganti apakah tagline tersebut belum efektif? Apakah tagline Enjoy Jakarta kurang mencerminkan kota Jakarta?. Hal tersebut juga didukung dengan pernyataan Catur Laswanto selaku Kepala Dinas Pariwisata dan Kebudayaan DKI Jakarta.

"Brand Enjoy Jakarta dirasa kurang selaras dengan nasional. Ada usulan branding itu harus memberikan kesan kuat terhadap Jakarta, sehingga ketika ditampilkan di media kesannya dalam," Kata Catur, di Balai Kota.

Adanya kelemahan yang disampaikan Catur Laswanto menjadi tantangan Dinas Pariwisata dan Kebudayaan DKI Jakarta untuk mensosialisasikan brand Enjoy Jakarta supaya tetap kuat memperlihatkan karakter Jakarta dimata dunia. Brand Enjoy Jakarta merupakan representative Jakarta terhadap wisatawan maupun masyarakat. Akan tetapi feedback dari brand tersebut belum sepenuhnya dirasakan oleh masyarakat. Hal ini tentunya harus didukung masyarakat Jakarta untuk membantu pemerintah mensosialisasikan brand Enjoy Jakarta bersama-sama.

Beberapa cara promosi yang dapat dilakukan oleh pemerintah baik untuk wisatawan dalam negeri maupun mancanegara yang ada di wilayah Provinsi DKI Jakarta adalah dengan memperkuat Positioning, Differentiation dan Branding (PDB) yang dimiliki oleh Jakarta. Dalam implementasi PDB tersebut, Jakarta memiliki positioning sebagai ibukota negara, tempat dimana pusat pemerintahan, bisnis dan berbagai kesempatan tersedia. Tentunya posisi tersebut akan berimplikasi pada differentiation atau keunikan yang dimiliki Jakarta, bahwa Jakarta merupakan wilayah yang bersifat melting pot yang menunjukkan adanya peleburan dan pertemuan 
berbagai kultur, etnis, agama sehingga mempengaruhi karakteristik wisata yang beragam dari wisata budaya hingga wisata kepulauan. Branding Jakarta adalah kota yang sangat bersahabat dengan pendatang, yang dipersentasikan dengan slogan Enjoy Jakarta.

Slogan Enjoy Jakarta memiliki pesan bahwa Jakarta pantas menjadi destinasi wisata favorit bagi wisatawan baik dari domestik mau pun dari mancanegara (Kartajaya, H dalam seminar pembekalan "Marketing Jakarta" Abang None DKI Jakarta 2016).

Pentingnya sektor pariwisata di Jakarta mendorong pemerintah untuk berpikir cerdas dalam mengembangkan sektor ini. Berbagai strategi dilakukan untuk semakin mengoptimalkan potensi pariwisata Jakarta. Sedangkan untuk memajukan industri kepariwisataan, diperlukan promosi wisata dan pengembangan sistem informasi kepariwisataan (Fauzie, H., Katjong, B K., \& Ainic, Q, 2012).

\section{RUANG LINGKUP}

Teori Excellent bagi Public Relations adalah kedalaman penelitian dan kesimpulan yang telah memberikan kontribusi terhadap cara Public Relations yang di praktikan. Grunig dan tim akademik yang terdiri dari Larissa Grunig, David Dozier, William Ehling, Jon White dan seorang praktisi Public Relaions Fred Repper melakukan penelitian untuk mengidentifikasi bagaimana dan mengapa Public Relations memberikan nilai kepada organisasi.

\subsection{Komunikasi}

Komunikasi adalah sarana interaksi manusia. Di dalam komunikasi termuat ide, perasaan dan pesan pesan tertentu. Supaya muatan komunikasi dapat dimengerti, manusia menggunakan bahasa. Dimengerti bukan hanya terkait memahami bahasa yang digunakan tersebut. Namun, dapat mengerti artinya memahami makna yang terkadang didalam komunikasi tersebut (Gassing S.S., \& Suryanto, 2016).

\subsection{Peran Public Relations Pemerintah}

Hubungan masyarakat dalam pemerintahan sangat penting karena filsafah dari negara dari rakyat, oleh rakyat dan untuk rakyat seperti yang dianut oleh negara demokrasi liberal, membuat layanan kepada masyarakat merupakan kewajiban utama. Rakyat turut mengawasi kegiatan pemerintah, supaya apa yang tidak sesuai dengan masyarakat rasakan dapat langsung dikritik. Demikianlah, maka lembaga - lembaga pemerintahan dari tingkat pusat hingga daerah mempunyai divisi humas untuk mengelola informasi dan opini public (Effendy, O. U., 2006).

\subsection{Teori City Branding}

City Branding dapat membantu dalam membuat baik kota yang diinginkan, Apakah kota dengan branding salah satu cara membuat perbedaan? Sebuah kota harus mempunyai kualitas yang sangat bagus untuk branding itu sendiri berhasil. Berbagai faktor terlibat diantaranya upaya antara masyarakat dan pemerintah kota salah satu kunci faktor dalam menentukan potensi sebuah kota. Pelajari berdasarkan penelitian sejarah, referensi, demografik, budaya, kejahatan, perkembangan ekonomi, lensa politik, penduduk atau warga, majalah, buku dan Word of mouth. (Winfield. J., 2005)

\subsection{Citra}

Citra adalah a picture of mind, yaitu gambaran yang berada di dalam benak seseorang (Holt, Rinehart, and Winston, 1996). Berikut beberapa definisi yang ditemukan para ahli: Huddleston (dalam Buchari Alma, 2008) mendefinisikan, "Citra adalah serangkaian kepercayaan yang dihubungkan dengan sebuah gambaran yang dimiliki atau diperoleh dari pengalaman"

Menurut Frank Jefkins (Soemirat S, \& Adriyanto, 2007), "Citra adalah kesan seseorang atau individu tentang sesuatu yang muncul sebagai hasil dari pengetauan dan pengalamanya".

\section{BAHAN DAN METODE}

Menurut Craswell (2010) (dalam buku Ardianto, 2014), metode penelitian deskriptif kualitatif termasuk paradigma penelitian post-positivistik, yang dimaksud penelitian post- positivism adalah pengetauan dibentuk oleh data, bukti dan pertimbangan logis. Penelitian harus mampu mengembangkan pernyataan yang relevan dan benar. Aspek terpenting dalam penelitian adalah sikap objektif.

Didalam metode kualitatif seseorang yang menjadi narasumber adalah kunci. Teknik pengumpulan data yang digunakan adalah observasi penelitinya, peneliti terlibat sepenuhnya dalam kegiatan informan kunci yang menjadi subjek penelitian dan sumber informasi penelitian (Ardianto. E., 2014).

Narasumber yang digunakan penulis dalam penelitian ini, ditujukan untuk mengetauhi efektivitas dan kegiatan sosialisasi Dinas Pariwisata dan Kebudayaan DKI Jakarta dalam penerapan Strategi Hubungan Masyarakat untuk mensosialisasikan Program Enjoy Jakarta.

\subsection{Teknik Pemeriksaan Keterpercayaan}

Analisis Trianggulasi yang digunakan dalam penelitian ini adalah Trianggulasi sumber. Data yang didapat dari beberapa sumber melalui proses pengumpulan informasi dan wawancara akan dilakukan pengecekan pada kepala Dinas Pariwisata dan Kebudayaan DKI Jakarta.

\subsection{Keterbatasan Penelitian}

Keterbatasan penelitian ini adalah belum adanya sosialisasi lebih yang dilakukan oleh pihak Dinas Pariwisata dan Kebudayaan DKI Jakarta dalam mensosialisasikan program Enjoy Jakarta, belum mempunyai data secara komperhensif dari seluruh stakeholders Enjoy Jakarta dan peneliti sedikit kesusahan 
untuk mengakses data di Dinas Pariwisata dan Kebudayaan karena data tersebut tidak dapat diperbolehkan disebarluaskan. Selama ini Enjoy Jakarta hanya didukung dengan penempelan logo disuatu acara pariwisata dan kebudayaan DKI Jakarta. Untuk sosialisasi program Enjoy Jakarta sendiri dari pihak Dinas Pariwisata dan Kebudayaan DKI Jakarta belum terlaksanakan semaksimal mungkin sehingga peneliti kekurangan sumber dari masyarakat sekitar.

\section{PEMBAHASAN}

Ada 4 nominasi logo Jakarta yang dipertimbangkan pada tahun 2004 yaitu Jakarta, It's Real!, There's More In Jakarta, Jakarta The Spice of Life dan Enjoy Jakarta. Proses seleksi tidak saja melibatkan dinas pariwisata, pemprov DKI tapi juga para stakeholders melalu forum Friends of Jakarta yang pada akhirnya diputuskan untuk memilih Enjoy Jakarta sebagai logo atau ikon kota Jakarta yang mewakili segala bentuk komunikasi kota Jakarta dalam konteks pariwisata. ialah:

Tujuan jangka panjang dari slogan terbaru Jakarta

1. Meningkatkan dan membangun citra kota Jakarta

2. Membangun awareness kota Jakarta sebagai destinasi wisata berkualitas

3. Meningkatkan respect publik terhadap Jakarta sebagai suatu ibukota gerbang Indonesia

4. Meningkatkan kunjungan ke kota Jakarta pada masa depan baik dari kalangan mancanegara maupun nusantara

Ke 4 poin penting diharapkan akan mengarah peningkatan frewensi pada;

a. Kunjungan untuk kegiatan bisnis,

b. Kunjungan untuk kegiatan wisata,

c. Kunjungan untuk kegiatan MICE (meeting, incentive, convention \& exhibition),

d. Yang akhirnya bermuara pada peningkatan pendapat kota baik pemerintah, bisnis dan penduduknya

\subsection{Filosofi Warna}

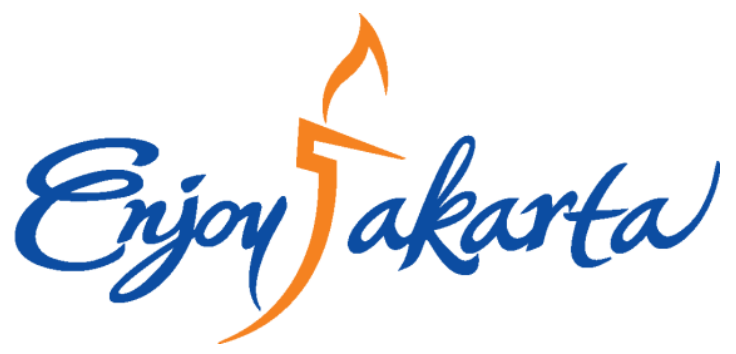

Gambar 1. Logo Enjoy Jakarta, Dari Dinas Pariwisata dan Kebudayaan DKI Jakarta 2017

Dapat dilihat pada gambar 1, Logo "Enjoy Jakarta" terdiri dari 2 warna, yaitu jingga dengan komposisi c0 m60 yi 00 k0 R245 g 130 b32; dan warna biru tua dengan kompisisi c1 00 m80 y0 k0 R3 g78 b162

\subsection{Dinas Pariwisata dan Kebudayaan DKI Jakarta}

Dinas Pariwisata dan Kebudayaan Provinsi Daerah Khusus Ibukota Jakarta merupakan Satuan Perangkat Kerja Daerah yang bertugas dan bertanggung jawab terhadap segala hal terkait kebudayaan dan kepariwisataan di Jakarta yaitu Jakarta Pusat, Jakarta Barat, Jakarta Timur, Jakarta Utara, Jakarta Selatan dan Kepulauan Seribu. Kantor Dinas Pariwisata dan Kebudayaan Provinsi DKI terletak di Jalan Kuningan Barat Nomor 1 Kota Jakarta Selatan dan memiliki situs resmi www.jakarta-tourism.go.id. Dengan slogan Enjoy Jakarta, situs resmi pariwisata dan kebudayaan Provinsi DKI Jakarta menyediakan berbagai informasi mengenai keanekaragaman budaya dan berbagai destinasi pariwisata bagi wisatawan dalam dan luar negeri yang ingin berkunjung ke Jakarta.

Perkembangan kepariwisataan di seluruh Indonesia, mendorong pemerintah DKI Jakarta mendirikan Organisasi yang bertugas khusus menangani kepariwisataan di Jakarta. Dinas Pariwisata DKI Jakarta berdiri dengan dasar Perda No. 3 Tahun 2001. Adapun Struktur Organisasi dan Tata Kerja dibentuk berdasarkan Peraturan Gubernur Provinsi DKI Jakarta No. 107 Tahun 2001.

\subsection{Visi Misi Dinas Pariwisata dan Kebudayaan DKI Jakarta}

Dengan memperhatikan kondisi objektif, potensi, permasalahan dan isu strategis yang dihadapi SKPD Dinas Pariwisata dan Kebudayaan Provinsi DKI Jakarta serta amanat, peraturan dan perundangan dalam perencanaan pembangunan daerah dan penyelenggaraan pemerintah di daerah dan arahan Pembangunan jangka panjangan Provinsi DKI Jakarta Tahun 2005-2025, maka visi SKPD Dinas Pariwisata dan Kebudayaan Provinsi DKI Jakarta Periode Tahun 2013-1017 adalah:"Mewujudkan Jakarta Baru sebagai kota berbudaya yang memiliki daya saing Pariwisata Global" Analisis Hasil Penelitian Dalam hal ini peneliti ingin menganalisis antara teori dan hasil wawancara dengan narusumber.

\subsection{Teori PR Excellent}

Strategi PR Excellent adalah untuk membangun hubungan antara organisasi dan publiknya dengan komunikasi dua arah dan simetris. Hal ini juga sebagai mungkin disampaikan dengan salah satu narasumber peneliti yang menyampaikan sebagai berikut:

"Berbicara Jakarta dengan city branding Enjoy Jakarta menurut saya memberikan pengaruh yang cukup besar sama tingkat destinasi pariwisata di Indonesia karena kebetulan kan memang Jakarta sebagai gerbang utama Indonesia" (Andara, Jakarta, Wawancara data primer, 25-April-2017). 


\subsection{Komunikasi internal dan eksternal}

Komunikasi Internal merupakan pertukaran informasi antara seluruh karyawan yang berada di perusahaan atau organisasi tersebut. Tujuan komunikasi Internal menyamankan persepsi, pola pikir dan arah padangan suatu perusahaan atau organisasi menjadi satu tujuan. Komunikasi internal dalam hal mengenai slogan Enjoy Jakarta menurut peneliti yaitu masyarakat Jakarta sendiri, karena sebagai masyarakat yang peduli terhadap kotanya juga harus mempromosikan apa saja yang ada di Jakarta. Hal ini disampaikan oleh salah satu narasumber peneliti sebagai berikut:

"Masyarakat Jakarta khususnya ketika belum merasakan tagline Enjoy Jakarta, justru kita ingin mengajak mereka untuk merasakan dan mencintai kotanya." (Alberto Ali, Jakarta, Wawancara data primer, 26-Mei-2017).

Komunikasi External dalam hal mengenai tagline Enjoy Jakarta menurut peneliti yaitu orang-orang yang berada di luar Jakarta. Menurut salah satu narasumber peneliti, Jakarta bukanlah destinasi wisata pertama untuk saat ini. Jakarta dikenal sebagai ibukota Indonesia dan jaringan dari penerbangan internasional yaitu Jakarta. (Hasiyanna S Ashadi, Wawancara data primer, 10 / Mei / 2017). Hal ini harus disosialisasikan dan dipromosikan secara terus-menerus, narasumber lainnya mengatakan sebagai berikut:

"Untuk mempromosikan pariwisata Jakarta itu banyak starteginya, dari kita melakukan promosi dari media sosial, melalui official website, melalui pameranpameran luar kota maupun luar negeri, itu salah satu bentuk promosi kita, lalu kita juga pernah membuat video-video iklan layanan masyarakat ya yang mempromosikan tentang kota Jakarta". (Alberto Ali, Jakarta, Wawancara data primer, 26-Mei-2017)

\subsection{Teori City Branding}

City Branding dapat membantu dalam membuat baik kota yang diinginkan, Apakah kota dengan branding salah satu cara membuat perbedaan? Sebuah kota harus mempunyai kualitas yang sangat bagus untuk branding itu sendiri berhasil. Sebagaimana disampaikan oleh narasumber peneliti sebagai berikut:

"Kalau berbicara Jakarta dengan city branding Enjoy Jakarta menurut saya memberikan pengaruh yang cukup besar sama tingkat destinasi pariwisata di Indonesia karena kebetulan Jakarta sebagai gerbang utama Indonesia". (Andara, Wawancara data primer, 25 / April / 2017)

\subsection{Citra}

Citra didalam penelitian ini adalah hasil apa saja yang sudah dikerjakan oleh Dinas Pariwisata dan Kebudayaan DKI Jakarta, lalu kemudian terbentuklah citra organisasi tersebut. Dari pembentukan citra terhadap suatu organisasi, maka program - program yang dijalankan Dinas Pariwisata dan Kebudyaan DKI Jakarta seperti Enjoy Jakarta akan dipandang baik.

Seperti yang sudah disampaikan narasumber Bapak Jacky diatas bahwa ada 3 teknik untuk menarik wisatawan datang ke Jakarta yaitu dengan cara membuat mereka aware terlebih dahulu, lalu appealing terhdapat Jakarta kemudian curious apa aja yang ada di Jakarta. Untuk memberik citra yang kuat ada satu cara terakhir supaya wisatawan tersebut ingin kembali lagi ke Jakarta yaitu follow up. Berhubungan baik kepada wisatawan membuka pemikiran mereka dengan adanya isu negative berubah menjadi bagian dari citra Jakarta.

(Wawancara data primer, 04-Mei-2017).

\section{KESIMPULAN}

Enjoy Jakarta merupakan salah satu hal yang krusial dan sebagai masyarakat Jakarta sudah seharusnya sadar akan itu, Enjoy Jakarta merapakan suatu program Dinas Pariwisata dan Kebudayaan DKI Jakarta untuk memperkenalkan, mensosialisasikan dan mempromosikan Jakarta kepada masyarakat diluar Jakarta dan luar negeri.

Berdasarkan hasil wawancara dengan narasumber diatas, peneliti menyimpulkan bahwa, upaya hubungan masyarakat Dinas Pariwisata dan Kebudayaan DKI Jakarta sudah melakukan sosialisasi kepada masyarakat Jakarta dengan melaksanakan program atau event di Jakarta yang menarik dan berkelanjutan setiap tahunnya, akan tetapi program tersebut berjalan ketika ada anggaran dari Dinas Pariwisata dan kebudayaan DKI Jakarta.

Hambatan dalam mensosialisasikan Enjoy Jakarta adalah pertama, kurangnya komunikasi antara organisasi dengan masyarakat dan stakeholders belum dilakukan lebih dalam lagi sehingga ada perbedaan pendapat mengenai target Enjoy Jakarta dan teknik pemasaran. Kedua, masyarakat Jakarta sendiri belum sepenuhnya sadar akan wisata, ini yang membuat hospitality kepada wisatawan Internasional dan lokal kurang. Cara mengatasi hambatan tersebut adalah Dinas Pariwisata dan Kebudayaan DKI Jakarta sudah seharusnya membuat suatu pertemuan untuk menyamaratakan kembali perbedaan tersebut, sehingga ketika disosialisasikan kepada target tidak terjadi adanya perbedaan persepsi.

\section{SARAN}

Untuk menambah kajian pada penelitian selanutnya, disarankan kepada peneliti yang ingin melanjutkan penelitian mengenai pariwisata kota Jakarta dapat ditekankan dari perspektif kekayaan budaya, sumber daya manusia, kekayaan alam, guna tetap menjadikan kota Jakarta sebagai kota favorit destinasi wisata. Menggunakan metode penelitian Kuantitatif dan menyebarkan kuesioner dapat memperlengkap penelitian tentang Enjoy Jakarta. Selain melanjutkan penelitian 
dengan sudut pandang dan objek yang berbeda, penelitian lanjutan pun dapat dilakukan untuk memperkenalkan kekayaan Indonesia dalam hal ini pariwisata nya supaya orang-orang semakin mengenal wisata-wisata di kota Indonesia.

\section{DAFTAR PUSTAKA}

Abang None. 2017 . Buku Panduan Abang None Jakarta Timur 2017. Jakarta, Indonesia.

Antara. 2016, September 25 . Tahun 2019 Pariwisata Diproyeksi Hasilkan Devisa Terbesar Bagi Indonesia. Diperoleh dari http://traveling.bisnis.com/read/20160925/224/58 6750/tahun-2019-pariwisata-diproyeksi-hasilkandevisa-terbesar-bagi-indonesia

Ardianto, E. 2014 . Metodologi penelitian untuk Public Relations: Kuantitatif dan Kualitatif. Bandung, Indonesia: Simbiosa Rekatama Media

Berita Jakarta, 2016 . Diperoleh dari http://www.beritajakarta.com/read/32940/DKI_Se laraskan_Branding_Wisata_dengan_Pemerintah_ Pusat\#.V-kru60UbIU

Butterick, K. 2014 . Pengantar Public Relations: Teori dan Public Praktik. Jakarta, Indonesia: RajaGrafindo Persada.

Cahyadi, R. 2012 . Aplikasi Cagar Budaya di Wilayah DKI Jakarta pada platform android. Diperoleh dari http://publication.gunadarma.ac.id/bitstream/1234 56789/5204/1/Jurnal\%20Ilmiah.pdf

Cangara, H. 2010 . Pengantar Ilmu Komunikasi. Jakarta, Indonesia: RajaGrafindo Persada

Dinas Pariwisata dan Kebudayaan DKI Jakarta, 2017 . Jakarta, Indonesia

Effendy, O. U. 2006 . Hubungan Masyarakat Suatu Studi Komunikasi. Bandung, Indonesia: Remaja Rosdakarya

Endraswara, S. 2006 . Metodi, Teori, Teknik, Penelitian Kebudayaan, Ideologi, Epistemologi dan Aplikasi. Sleman, Indonesia: Pustaka Widyatama.

Enjoy Jakarta, Data \& Statistics. The Number of foreign tourist maret 2016. Diperoleh dari http://www.jakarta-tourism.go.id/data-statistics

Fauzie, H., Katjong, B. L., \& Aini, Q. 2012. Pengembangan kios informasi pariwisata propinsi daerah khusus ibukota Jakarta. Diperoleh dari http://journal.uinjkt.ac.id/index.php/sisteminforma si/article/download/3021/2396

Gassing, S. S. \& Suryanto. 2016 . Public Relations. Yogyakarta, Indonesia: Andi Offset

Grunig. L. E., Grunig. J. E., \& Dozier, D. M. 2002 . Public Relations and effective Organizations. Newyork, USA: Routledge

Havid W, K. 2009 . Peran Humas Untuk Mengangkat Citra Pemerintahan Kota Surakarta. Diperoleh dari https://eprints.uns.ac.id/5320/1/431_ secured .pdf
Intyaswono, S., Yulianto, E., \& Mawardi, M. K. 2016 . Peran Strategi City Branding Kota Batu Dalam Trend Peningkatan Kunjungan Wisatawan Mancanegara: studi pada Dinas Pariwisata dan Kebudayaan Kota Batu. Diperoleh dari http://administrasibisnis.studentjournal.ub.ac.id/in dex.php/jab/article/view/1188

Istijanto. 2009 . Praktis Riset Pemasaran: cara praktis meneliti konsumen \& pesaing. Jakarta, Indonesia: Gramedia Pustaka Utama

Jakarta.go 2017 Rencana Strategi Dinas Pariwisata Dan Kebudayaan Provinsi DKI Jakarta Tahun 20132017 Diperoleh dari

http://www.jakarta.go.id/v2/uploads/embed/renstr a/EKONOMI/pariwisata/files/res/downloads/book .pdf

Jakarta Pedia 2015, November Tugas, fungsi dan struktur organisasi Diperoleh dari http://jakartapedia.bpadjakarta.net/index.php/Dina s_Pariwisata_dan_Kebudayaan_Provinsi_DKI_Ja karta

Juliand, A., Irfan., \& Manurung, S. 2014 . Metodologi Penelitian Bisnis: konsep dan aplikasi. Medan, Indonesia: OMSU Press.

Kartajaya, H. 2016 dalam pembekalan "Marketing Jakarta" Abang None DKI Jakarta

Kertopati, L. 2016, September 5 . Bulan Juli, Satu Juta Wisman Kunjungi Indonesia. Diperoleh dari CNN Indonesia, http://www.cnnindonesia.com/gayahidup/20160905204511-269-156286/bulan-julisatu-juta-wisman-kunjungi-indonesia/

Komunika Warta Ilmiah Populer Komunikasi Dalam Pembangunan. 2006 . Transformasi Usaha Industri Media Massa. Jakarta, Indonesia: LIPI

Kriyantono, R. 2006 . Teknik Praktis Riset Komunikasi. Jakarta, Indonesia: Kencana

Mahendra, A. 2017 . Buku Panduan Pemilihan Abang None Jakarta Timur. Jakarta, Indonesia.

Maskur. 2015 . Manajemen humas pendidikan islam: teori dan aplikasi. Yogyakarta, Indonesia: Deepublish

Nova, F 2009 . Crisis Public Relations. Jakarta, Indonesia: Grasindo

Nurjaman, K,. \& Umam, K. 2012 . Komunikasi \& Public Relations. Bandung, Indonesia: Pustaka Setia

Nurudin. 2016 . Ilmu Komunikasi: Ilmiah dan Populer. Jakarta, Indonesia: RajaGrafindo Persada.

Pawito. 2008 . Penelitian Komunikasi Kualitatif. Yogyakarta, Indonesia: LKIS Yogyakarta.

Perhumas Untuk Indonesia. 2008 . Branding The Nation studi kasus Public Relations Indonesia. Jakarta, Indonesia: BPP PERHUMAS

Ruslan, R 2016 . Etika Kehumasan konsepsi \& aplikasi. Jakarta, Indonesia: Grasindo

Winfield, J. 2005, The Branding Cities, exploring city branding the importance of brand image. USA. 